RESEARCH ARTICLE

\title{
Evaluation of Follow-up Results in Children with Henoch-Schönlein Purpura
}

\author{
Dursun Eryılmaz ${ }^{1}$, Aydın Ece $^{2}$ \\ ${ }^{1}$ Istanbul Şafak Hastanesi, Çocuk Yenidoğan Ünitesi, istanbul, Türkiye \\ ${ }^{2}$ Dicle Üniversitesi Tıp Fakültesi Çocuk Nefrolojisi \&Romatolojisi BD, Diyarbakır, Türkiye
}

\begin{abstract}
Objective: The aim of this study was to investigate long-term follow-up results of children Henoch-Schönlein purpura (HSP).

Methods: 102 children (66 boys and 36 girls) with HSP followed up at Pediatric Department of Dicle University Faculty of Medicine between 1996 and 2002 were included. Demographic, clinical and laboratory characteristics of children, treatment modalities and complications were reviewed from the follow-up charts of patients. Fourty-eigth children who came to control after a period of $40.8 \pm 19.9$ months underwent a thorough clinical and laboratory work up. Clinical and laboratory findings accompanying specific organ involvements were investigated.

Results: In total, $91.2 \%$ had purpuric eruption, $62.7 \%$ had gastrointestinal system (GIS) involvement, $28.4 \%$ had renal involvement and $43.1 \%$ had arthritis. Triggering factors were upper respiratory tract infection in 55\%, vaccination in 2 and drugs in 2 patients. Gastrointestinal involvement was significantly more frequent in children with high immunglobulin A levels $(p=0.012)$, renal involvement was significantly more frequent in children with high erythrocyte sedimentation rate $(p=0.006)$. GIS involvement was more frequent in patients over 7 years $(p<0.05)$. Significant correlations were found between renal involvement and leukocytosis, thrombocytosis and high C-reactive protein levels $(p<0.05)$. Mean healing period of the disease was $17.8 \square 9.2$ days. First relapses occurred in 42 patients $(41.2 \%)$ with skin eruptions and in $33(32.4 \%)$ with abdominal discomfort. Symptoms and signs were relapsed two times in 12 patients and three times in 13. The existence of hypertension, older age, low C3 levels were found to be associated with renal involvement in logistic regression analysis $(p<0.05)$.
\end{abstract}

Conclusion: Increased IgA level and age over 7 were associated with GIS involvement, while high acute phase reactants and older age were found to be related with renal involvement. J Clin Exp Invest 2016; 7(4): $269-277$.

Key Words: Henoch-Schönlein Purpura, children, clinical findings, laboratory findings, follow up results

\section{GiRiş}

Henoch-Schönlein purpurası, çocukluk çağında en sık görülen sistemik vaskülittir. Hipersensivite vaskülitleri için deri bulguları, özellikle purpura, tanı koydurucudur. Bunun yanında HSP, kan damarlarının inflamasyonu sonucu özellikle böbrek olmak üzere pek çok sistemi etkilemektedir. Hastalık, genellikle kendiliğinden iyleşebilmesi, iyi bir prognoza sahip olması yanında, çocukluk yaş gurubunda nadiren oluşan ciddi böbrek tutulumu ve hayatı tehdit eden GiS komplikasyonları nedeni ile önem taşımaktadır [1].
Çocukluk çağının en sık karşılaşılan vasküliti olması ve semptomlarının çok çeşitli olması nedeni ile de HSP, kliniğimizde yatırılan hastalıklar içinde önemli bir yer tutmaktadır.

Bu çalışmada HSP'li çocukların ilk tanı anında ve izleminde gözlemlediğimiz klinik ve laboratuvar bulguları ile ortaya çıkan komplikasyonlar ve bu durumların hastalara ait değişik özelliklerle ilişkisinin araştırıması amaçlanmıştır.

\section{HASTALAR VE METOT}

Bu çalışmaya; 1996-2002 yılları arasında Dicle Üniversitesi Tıp Fakültesi Çocuk Sağlığı ve Hastalıkları Anabilim Dalı'na başvurup, tipik deri 
döküntüleri ve buna eşlik eden diğer organ tutulumları, dikkate alınarak klinik olarak HSP tanısı konup, tetkik ve tedavisi yapılan 102 hasta alındı. Tüm hastaların izlem dosyalarından; yaş, cinsiyet, hastalık başlangıç yaşı, başvurudan önce hastanemiz dışında izlendiği süre, total izlem süreleri, ağırlık ve boy persentilleri, fizik muayene bulguları, kan basıncı (TA), başlangıç proteinürisi, immunglobulin $A(\lg A)$, kompleman faktör 3 (C3), kompleman faktör 4 (C4), Biyokimya: total protein, üre, kreatinin, ürik asit, sodyum, potasyum, kalsiyum, fosfor, asparta aminotransferaz (AST), alanin aminotransferaz (ALT), alkalen fosfataz (ALP), laktat dehidrogenaz (LDH), trigliserid (TG), total kolesterol (TK); Tam kan sayımı [hemoglobin $(\mathrm{Hb})$, hematokrit $(\mathrm{Htc})$, Trombosit sayısı], Periferik yayma (PY), tam idrar incelemesi (TiT), eritrosit sedimantasyon hızı, boğaz kültürü, anti streptolizin-O (ASO), C-reaktif protein (CRP), romatoid faktör (RF), batın USG bulguları, saptanabilen etyolojik faktörler, mevsimsel dağıım, komplikasyonlar ve tedavileri bakımından geriye dönük olarak incelendi.

Hastalardan 48'i çağrıya uyarak kontrole geldiler. Bunların toplam izlem süresi 40,8 \pm 19,9 ay idi. Elli-dört hasta ise son kontrol çağrısına yanıt vermemekle birlikte $13,0 \pm 6,5$ ay süreyle izlenmişlerdi. Bu hastalara ait veriler de hasta kartlarından bulunarak değerlendirmeye alındı. Tüm çocuklarda: tekrarlayan hastalık bulguları, yaş, cinsiyet, ağılık, boy persentilleri, başlangıç proteinürisi, kan basıncı (TA) ve ilk tanı anında yapılan tetkiklerin tekrarı yapıldı. Mutlak lökosit sayısı $10.000 / \mathrm{mm}^{3}$ üzeri lökositoz olarak kabul edildi. Santrifüj edilmiş idrarın x 40'lık büyütme bakısında beşten fazla eritrosit görülmesi mikroskopik hematüri, 5'ten fazla lökosit görülmesi lökositüri olarak kabul edildi. Stickle bakılan idrarda proteinüri pozitif bulunanlarda 24 saatlik idrarda kantitatif proteinüri ölçüldü. Sedimantasyon hızı $15 \mathrm{~mm} / \mathrm{saat}$ 'in üzeri yüksek olarak kabul edildi. Ayrıntılı fizik muayeneleri yapıldı. Elde edilen verilerin birbirleri ile ilişkileri, sistem tutulumu ve oluşan komplikasyonlar ile ilgileri, değişik sistem tutulumu durumunda oluşan farkları araştırıldı.

\section{İstatistiksel Analiz}

Çalışmada elde edilen verilerin toplanması tamamlandıktan sonra; veriler, bağımlı ve bağımsız gruplar için t-testi, Chi-kare testi,
Mann-Whitney $U$ testi, Odds oranı, Pearson korelasyon analizi, lineer ve lojistik regresyon analizi yöntemleri ile analiz edildi. $\mathrm{P}$ değeri 0,05 'in altı anlamlı kabul edildi.

\section{BULGULAR}

HSP'li 102 hastanın 66'sı (\% 64,7) erkek, 36'sı $(\% \quad 35,3) \quad$ kız çocuklardan oluşmaktaydı. Çocuklarda erkek / kız oranı 1,8/1 (66/36) olarak bulundu.

Hastaların yaş ortalaması 9,2 2,7 (2,5-14) yıl olarak saptandı. Hastaların en küçüğü 2,5 yaşında, en büyüğü ise 14 yaşında idi. Grafik 1 'de hastaların cinsiyet ve yaş gruplarına göre dağılımı verilmiştir. Hastaların ağırlık persentilleri ortalama 40,3, median (min-maks) 50 (3-95), boy persentilleri: ortalama 30,8, median (minmaks) 50 (3-95) idi.

Çalışmaya alınan 102 hastadan 48'i (\%47,1) son kontrol çağrımıza uyarak gelmiş ve tetkik yaptırmış, 54 hastaya ulaşılamamıştır. Kontrole gelenler $40,8 \pm 19,9$ ay süreyle, gelmeyenler $13,0 \pm 6,5$ ay süreyle izlenmiş olmaktadır. Grafik 2 'de çağrımıza uyarak kontrole gelen hastalar için total izlem süreleri verilmiştir.

Çalışmaya alınan hastaların hastanemize başvurmadan önceki döneme ait izlem süreleri dağılımı incelendiğinde, son kontrole gelenlerde dışarıda izlenen süre ortalaması $0,9 \pm 3,0$ ay, median (min-maks) 0 (0-24), son kontrole gelmeyenlerde ise) $0,5 \pm 2,5$ ay median (minmax): 0 (0-18) olduğu görüldü (Grafik 3).

Çalışmaya alınan hastalarımızın başvuru anındaki yakınmaları sıklık sırasına göre: deri döküntüsü \% 84,3 (86 hasta), karın ağrısı \% 60,7 (62 hasta), artralji \% 41,2 (42 hasta), öksürük \% 41,2 (42 hasta), ateş \% 26,5 (27 hasta), ödem \% 25,5 (26 hasta), hematüri \% 12,7 (13 hasta), kusma \% 18,2 (19 hasta), ishal $\%$ 12,6 (13 hasta), hematemez \% 6,9 (7 hasta), siyah renkli dışkı \% 9,6 (10 hasta) oligüri \% 2,9 (3 hasta) olarak bulundu. Hastaların 16'sında (\% 15,7) başvuru anında purpurik deri döküntüsü yoktu. Ancak bu hastaların 7'sinde hastanede yatarken döküntüler oluştu, 9'unda ise başvurmadan 5-30 gün önce deri döküntüsünün oluşup bir süre sonra kaybolduğu anamnezi alındı. Anamnezden döküntülerin 16 hastada (\% 15,7) karın ağrısından 3-25 gün sonra, 26 hastada $(\% 25,5)$ ise artraljiden 5-15 gün sonra ortaya çıktığı öğrenildi. Hastaların 78 'inde (\% 
76,5) ailenin dikkatini çeken ilk bulgu deri döküntüleri idi. Sekiz hastada döküntü, eklem şikayetleri ve karın ağrısının 1-2 yıldan beridir olduğu, zaman zaman tekrarladığı öğrenildi.

Hastaların 91,2'sinde (93 hasta) palpabl purpura denilen tipik deri döküntüleri gözlendi. Şiddetli karın ağrısı, kusma, hematemez ve / veya melenası olan veya dışkıda gizli kan bulunanlarda, GiS tutulumu olduğu kabul edildi ve Gis tutulumu \% 62,7 oranında (64 hasta) saptandı. Ayrıca \%28,4 oranında (29 hasta) mikroskopik ve makroskopik hematüri ve / veya proteinüri şeklinde belirti veren böbrek tutulumu vardı. Hastaların \% 43,1'inde (44 hasta), çoğunlukla ayak bileği ve diz, daha az oranda ise el bileği, el ve ayak parmaklarını etkiliyen eklem tutulumu; $\% 25,5$ oranında (26 hasta) lokal tarzda, periorbital, dudak, ile el-ayak sırtında bulunan ödem mevcuttu. Grafik 4 de belirli sistem tutulumları bulunan hasta sayıları, Grafik 5 de ise yaş gruplarına göre sistem tutulumlarının yüzdesi verilmiştir.

Cinsiyet ile GiS tutulumu, renal tutulum, artrit, artralji, ödem, ateş, öksürük, hematüri, oligüri, akut böbrek yetmezliği (ABY), hipertansiyon, C3 ve C4 değerleri ve hasta yaşı arasında anlamlı bir ilişki bulunamadı $(p \square 0,05)$.

Sistem tutulumlarının yaş gruplarına göre dağıımı (GiS tutulumu, renal tutulum, artrit) önemli farklıık gösteriyordu (Grafik 5). Ayrıca yaş gruplarına göre artralji varlığı $\left(\square^{2}=12,3\right.$, $p=0,031)$ ve $C 3$ düşüklüğü dağılımı anlamlı farklılık gösteriyordu $\left(\square^{2}=10,6, \quad p=0,039\right)$. Bununla birlikte yaş gruplarına göre döküntü, ödem, ateş, öksürük, olgüri, hematüri, $A B Y$, hipertansiyon varlığı ve $\mathrm{C} 4$ değerleri dağılımında anlamlı bir fark bulunamadı $(p>0,05)$.

Hastalarımızı yedi yaş ve altı ile yedi yaş üstü olarak sınıflandırıp bazı klinik ve laboratuvar özellikler yönünden değerlendirdiğimizde; yedi yaş üstü çocuklarda GiS tutulumu, ASO ve IgA değerleri yedi yaş ve altı çocuklardan anlamlı yüksek bulundu. Böbrek tutulumu ve yüksek sedimantasyon oranı istatistiksel olarak önemli olmamasına rağmen yedi yaş üstünde daha yüksek olarak bulundu (Tablo 1 ).

IgA yüksek olan hastalarda GiS tutulumunun daha sık olduğu gözlendi (OR= 2,9; $\% 95 \mathrm{Cl}: 1,2$ $6,8) \quad(p=0,012)$. Renal tutulumu olanlarda sedimantasyon hızı yüksekliği renal tutulum olmayanların yaklaşık 5 katı idi ( $\mathrm{OR}=4,7 ; \% 95$ $\mathrm{Cl}=1,6-13,6)(\mathrm{p}=0,006)$.

Renal tutulumu olanlarda GiS semptomları, diğerlerine göre daha yüksek oranda bulunurken, eklem tutulumuna daha düşük oranda rastlandı. Ancak bu farklar istatistiksel olarak önemli bulunmadı (Tablo 2). Renal tutulum ile ödem, hipertansiyon, C3 ve yüksek sedimantasyon hızı arasında anlamlı ilişki var iken (Tablo 3), renal tutulum ile ateş, oligüri, $A B Y$ gelişimi ve C4 arasında bir ilişki bulunamadı (Tabloda gösterilmedi) ( $p>0,05)$. Ayrıca renal tutulum ile lökositoz $(p=0,004)$, trombositoz $(p=0,003)$ ve CRP yüksekliği $(p=0,003)$ arasında anlamlı korelasyon bulundu.

Lojistik regresyon analizi ile yaş $(R=0,19 ; p=$ $0,011)$, hipertansiyon varlığı $(R=0,23 ; p=0,004)$ ve C3 değeri düşüklüğü $(R=0,13 ; p=0,045)$ renal tutulum üzerine belirleyici bulundu.

Nefrotik sendrom gelişen çocuklardan dördüne böbrek ince iğne biyopsisi yapıldı, histopatolojik incelemelerde HSP nefriti ile uyumlu olarak glomerüllerde çeşitli oranlarda skleroz gösteren proliferatif nefrit saptandı. Hastalardan birisi beş yılda son dönem böbrek yetmezliğine girdi ve periton diyalizi açıldı. Diğer 4 hasta 11ay-2 yıllık takipten sonra, çeşitli nedenlerden dolayı kontrolden çıktılar.

Hastalarımızın \%55'inde (56 hasta) döküntüden 1-4 hafta önce ÜSYE enfeksiyonu öyküsü vardı. Hastaların başvuru anında \% 41,2'sinde (42 hasta) öksürük mevcuttu. Bu hastaların 16'sında $(\% 28,5)$ boğaz kültüründe beta hemolitik streptokok üredi.

Hastaların kan basıncı izlemlerinde sistolik ve/veya diyastolik kan basıncı yaş ve cinse uyan 95. persentilin üzerinde olanlar hipertansif kabul edildi. Yapılan ölçümler sonucunda \% 8,8 oranında (9 hasta) hipertansiyon tespit edildi. Yatış anında anormal idrar bulgusu olanlarda hipertansiyon sıklığı (7/29), renal tutuluma ilişkin idrar bulgusu olmayanlardan (2/73) istatistiksel olarak anlamlı yüksekti (OR: 112, \% $95 \mathrm{Cl}$ : 21583) $(p<0,001)$. Öte yandan Hipertansiflerin sadece ikisinde yatış anında anormal idrar bulgusu yoktu. Diğerlerinde ise anormal idrar bulgusu vardı, takiplerde idrar bulguları devam etse bile hipertansiyon düzeldi. Hipertansif hastaların beşinde, ilk başvuru anında yapılan renal USG sonuçları parankim ekojenitesi artışı 
şeklinde idi, dört hastada ise USG görüntüleme normal bulundu ve hipertansiyon-anormal USG bulgusu arasında anlamlı ilişki vardı $(p=0,002)$. Son kontrollerde yapılan USG de tüm hastalarda renal parankim ekojenite artışının kaybolduğu görüldü. Hastaların ilk başvuru ve son kontrollerindeki sistolik ve diyastolik tansiyon değerleri arasında anlamlı bir ilişki bulunamadı

Erkek hastalarımızın 13'ünde (\% 12,7) testis tutulumuna rastlandı. Bunların 6'sında testiste ödem, 5'nde skrotum ve peniste purpura, 2'sinde skrotal ödem ve ağrı saptandı, ancak gerçek testis torsiyonuna rastlanmadı.

Hastaların ilk başvuru anında yapılan laboratuvar tetkiklerinde serum albumin ile 24 saatlik idrar protein değeri, beyaz küre (BK), CRP ve sedimantasyon hızı arasında önemli korelasyonlar bulundu. Yüksek 24 saatlik idrar proteini bu hastalardaki serum albumin değerinin düşüklüğünü açıklamaktadır. Pearson bivariate korelasyon analizi ile (hastalığın başlangıcında 24 saatlik idrarda proteinürisi olanlar da), başlangıç protenüri değeri ile $\mathrm{BK}$ arasında $(r=0,27 ; p=0,01)$, CRP ile proteinüri $(r=0.21$; $p=0,01)$ ve sedimantasyon hızı ile proteinüri düzeyi arasında $(r=0,26 ; \quad p=0,01) \quad$ pozitif korelasyonlar bulundu.

Kontrole gelen hastalarda ilk başvuru ve son kontrol idrar bulguları kıyaslandığında aralarında anlamlı ilişki vardı $(P=0.002$, OR: $7,0, \% 95 \mathrm{Cl}$ : 1,3-38,6). Illk başvuru anında, anormal idrar tetkik sonucu bulunanlarda, renal pozitif USG bulgusu (parankim ekojenite artışı) sıklığı $(11 / 37, \% 29,7)$, idrar bulgusu normal olanlara göre ( $3 / 65, \% 4,6)$ anlamlı yüksekti (OR: 8,$7 ; \mathrm{Cl}$ : $2,3-33,9)(p=0,001)$. Kontrole gelen hastaların ilk başvuru anında yapılan renal USG de pozitif bulgu sıklığı $(5 / 43, \% 11,6)$, son kontrollerindeki renal USG bulgu sıklığından $(2 / 46, \% 4,3)$ anlamlı yüksekti (OR: 1,4, \% $95 \mathrm{Cl}$ : 0,88-2.34) $(p=0,002)$.

Hastaların ilk başvuru anında yapılan 88 boğaz kültüründen 47 'sinde $(\% 60,3)$ normal boğaz florası görülürken, 31 hastada $(\% 39,7)$ beta hemolitik streptokok üredi. İlk başvuruda 24 hastada boğaz kültürü sonucu bulunamadı. Hastaların son kontrollerinde 14 hastada (\% $29,2)$ üreme olmazken 34 hastada $(\% 70,8)$ beta hemolitik streptokok üredi. Illk başvuru ve son kontrollerde boğaz kültüründe beta hemolitik üreme oranları arasında anlamlı fark bulundu $(\mathrm{p}<0,001)$.

Hastaların ilk başvuru anındaki laboratuvar bulgularından anormal olanlar sıklık sırasına göre; yüksek sedimantasyon hızı \% 85 (87 hasta), yüksek C3 \% 79 (81 hasta), yüksek IgA $\% 71$ (72 hasta), trombositoz \% 55 (56 hasta), yüksek CRP \% 50,9 (52 hasta), yüksek ASO \% 36,3 (37 hasta), yüksek beyaz küre sayısı \% 24,5 (25 hasta) olarak bulundu.

Hastalarımız en sık eylül-kasım aylarında, yani sonbaharda (\% 39,2), giderek azalan sıklıklarda, kış $(\% 29,4)$, ilkbahar $(\% 19,6)$ ve yaz $(\% 11,8)$ aylarında başvurmuşlardı. Öyküden tetikleyici faktör olarak 56 hastada (\% 55) hastalıktan 1-4 hafta önce gelişen üst solunum yolu enfeksiyonu, 2 hastada aşılama ve 2 hastada ise ilaç alımı bulundu.

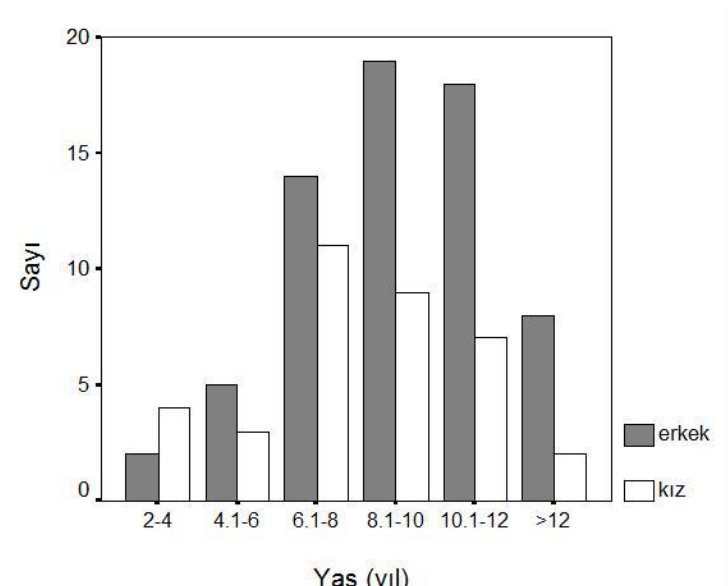

Grafik 1. Çalışma grubunu oluşturan HenochSchönlein purpuralı çocukların cinsiyet ve yaş grupların göre dağılımı.

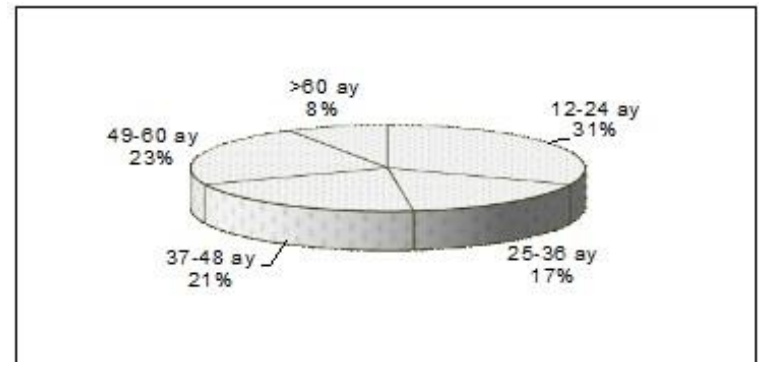

Grafik 2. Son kontrole gelen hastaların izlem süresine göre dağılımı. 
Hastalığın iyileşme süresi ortalama 17,8 $\pm 9,2$ gün olarak bulundu. Hastalarımızın 42'sinde (\% $41,2)$ döküntü, 33'ünde (\% 32,4) karın ağrısı tekrarladı. Purpurik döküntüleri tekrarlayan hastaların yaşları, tekrarlamayanlardan anlamlı yüksekti $(10,2 \pm 1,8$ yıl ve $8,2 \pm 2,4$ yıl). Karın ağrısı tekrarlayanlarda lökosit sayısı tekrarlamayanlardan yüksekti $\left(14600 \pm 5300 / \mathrm{mm}^{3}\right.$ ve $\left.9300 \pm 3700 / \mathrm{mm}^{3}\right)(p<0,0001)$.

Hastalığı tekrarlayanların, 12'si taburcu olduktan sonra ikinci kez kliniğimize yatırılıp tedavisi yapılmıştır. Bu hastaların 4'ünde bir hafta, 2'sinde on gün, 3'ünde 3 hafta, 3'ünde de bir ay sonra tekrarlama saptanmıştır.

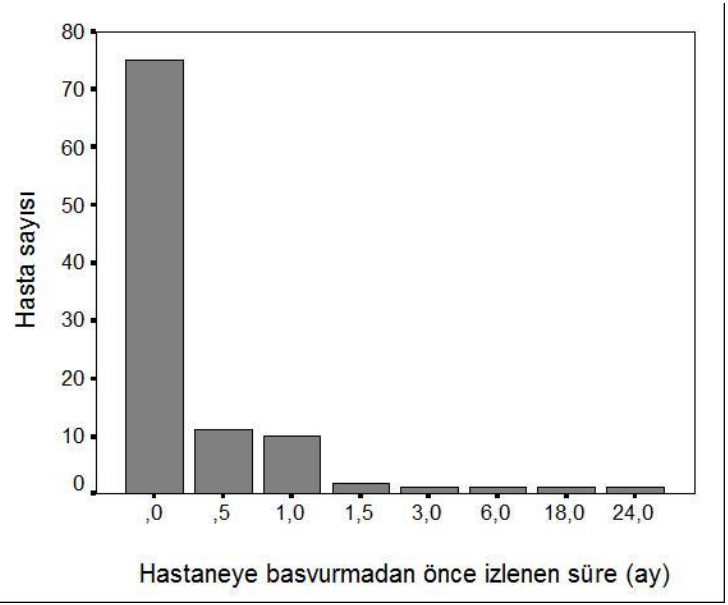

Grafik 3. Henoch-Schönlein purpuralı çocukların hastanemize başvurmadan önceki döneme ait izlem süreleri dağılımı.

Hastaların 6'sında $(\% 5,9)$ döküntü, 5 hastada $(\% 4,9)$ karın ağrısı, 2 hastada (\% 1.9) artrit üçüncü kez tekrarladı. Döküntü ve GiS tutulumunun tekrarladığı hastaların tümü 7 yaş üzerinde idi ve yaş ortalaması sırası ile 10,6 \pm 1,4 yıl ve $9,4 \pm 1,6$ yıl olarak bulundu.

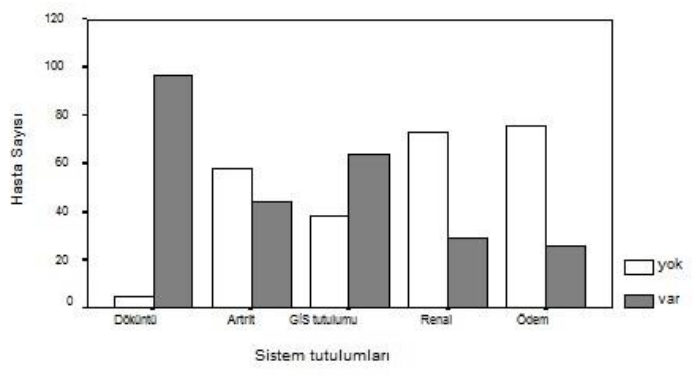

Grafik 4. Çeşitli sistem tutulumları olan ve olmayan hasta sayıları

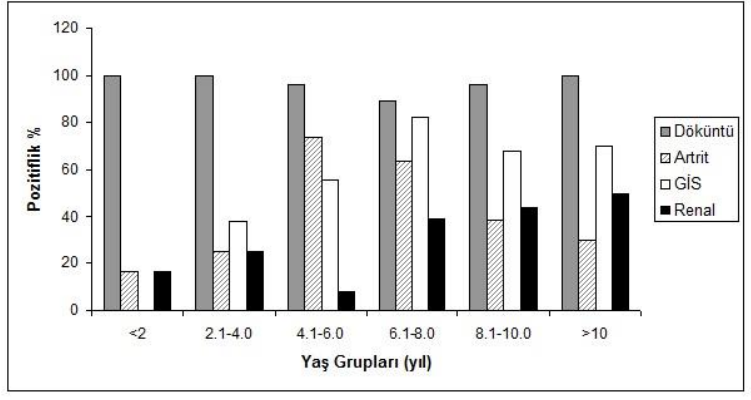

Grafik 5. Yaş gruplarına göre sistem tutulumları yüzdeleri.

\section{TARTIŞMA}

Henoch-Schönlein purpurası çocukluk çağının en sık rastlanan ve küçük damarları tutan bir vaskülitidir. Hastalık selim seyretmesine rağmen HSP'de en sık morbidite nedeni olan GiS ve renal tutulumu için prediktif değeri olan klinik ve laboratuvar bulguların saptanması, hangi hastaların hastanede daha uzun süre tutulması ve hangi özellikleri taşıyan hastaların ayaktan daha sık ve uzun süreli izlenmesi gerektiğini göstermesi açısından önem taşımaktadır.

Çalışmamıza, HSP tanısı konulan, tetkik ve tedavisi yapılan 102 hasta alındı. Hastaların dosyaları geriye dönük olarak incelendi. Bu hastalardan 48 olgu ileriye dönük (prospektif) olarak ortalama 3 yılık bir süre sonunda kontrole çağrılıp hastalığın klinik seyri ve laboratuvar değişiklikleri, bulguların ve laboratuvar parametrelerinin birbirleri ile ilişkileri, sistem tutulumu için risk faktörleri belirlenmeye çalışıldı.

Çalışmamız kapsamında olan 102 hastanın en küçüğü 2,5 yaşında, en büyüğü 14 yaşında bulunmuştur. Literatürde 2 yaş altında hastalar görülebildiği de bildirilmiştir [1].

Hastalarımızda erkek / kız oranı 1,8/1 (66/36) olarak erkek çocuklar lehine bulduk. literatürdeki diğer çalışmalarda bu oran 1,2/1'den 2,6/1'e değişen oranlarda olmak üzere genellikle erkek çocuklar lehine bulunmuştur [1]. 
Table 1. Yedi yaş ve altı ile yedi yaş üstü Henoch-Schönlein purpuralı çocukların bazı özelliklerindeki farklııkları.

\begin{tabular}{lccc}
\hline Özellikler & $\mathbf{7}$ yaş ve altı (23 hasta), $\mathbf{n}(\%)$ & $\mathbf{7}$ yaşüstü $(\mathbf{7 9}$ hasta), $\mathbf{n}(\%)$ & $\mathbf{p}$ \\
\hline Eklem tutulumu & $12(52,2)$ & $32(40,5)$ & $\geq 0,05$ \\
GiS tutulumu & $6(26,1)$ & $58(73,4)$ & $<0,001$ \\
Renal tutulum & $4(17,4)$ & $25(31,6)$ & $\geq 0,05$ \\
Hipertansiyon & $0(0)$ & $9(11,4)$ & 00,05 \\
Yüksek ASO & $3(13,1)$ & $33(41,8)$ & $\geq 018$ \\
Yüksek sedim & $15(62,3)$ & $67(84,4)$ & $\geq 0,05$ \\
Yüksek IgA & $13(56,6)$ & $59(74,4)$ & 0,017 \\
\hline AD=Anlamlı değil & & &
\end{tabular}

Table 2. Henoch-Schönlen purpuralı çocuklarda renal tutulum durumuna göre gastrointestinal sistem ve eklem tutulum oranları.

\begin{tabular}{lcccccc}
\hline Parametreler & \multicolumn{2}{c}{ Gis tutulum } & \multicolumn{2}{c}{ Renal tutulum } & 'OR (\%95 Cl) & ${ }^{2}$ OR (\%95 Cl) \\
\hline Renal tutulum & ${ }^{1}$ Var & ${ }^{1}$ Yok & ${ }^{2}$ Var & ${ }^{2}$ Yok & & \\
Var & 21 & 8 & 11 & 18 & $1,8(0,7-4,68)$ & $0,7(0,3-1,8)$ \\
Yok & 43 & 30 & 33 & 40 & & \\
Toplam & 64 & 38 & 44 & 58 & \\
\hline
\end{tabular}

GiS: Gastrointestinal sistem, OR: Odds ratio, Cl: güven aralığı

Tablo 3. Renal tutulum ile ödem, hipertansiyon, C3 yüksekliği ve sedimantasyon yüksekliği ilişkisi

\begin{tabular}{lccc}
\hline Parametreler & Renal Tutulum Varlı̆̆ (n=29) N (\%)* & $\mathbf{p}$ & Odds Oranı (\%95CI) \\
\hline Ödem & $17(65,4)$ & $<0,001$ & OR: $10,1(3,6-27,8)$ \\
Hipertansiyon & $7(77,8)$ & 0,01 & OR: $11,3(2,2-58,4)$ \\
C3 Yüksekliği & $27(33,3)$ & 0,033 & OR: $4,8(1,1-21,9)$ \\
\hline EÇH Yüksekliği & $24(39,3)$ & 0,003 & OR: $4,7(1,6-13,6)$
\end{tabular}

*Satır yüzdeleri; $\mathrm{Cl}=$ Güven aralığı; EÇH=Eritrosit çökme hızı 
JCEI /

Journal of Clinical and Experimental Investigations

Henoch-Schönlein purpuralı çocuklarda palpabl purpura da denilen tipik deri döküntüleri tanıda çok önemlidir. Hastaların tümünde döküntüler gözükür ancak başlangıç bulgusu olarak deri döküntüsü tüm hastalarda olmayabilir. Literatürde başlangıç bulgusu olarak deri döküntüsü görülen hastaların oranı $\% 50$ ve üzeri olarak belirtilmektedir, Hastalarımızda başlangıç bulgusu olarak deri döküntüsü \% 843 (86 hasta), oranında idi, bu oran literatür ile uyumlu bulundu [1].

Hastalarımızın \% 14,7'sinde başvuru sırasında tipik deri döküntüleri yoktu bu hastalardan 7'sinde karın ağrısı, 6'sında karın ağrısı + ishal, 2'sinde ise karın ağrısı + kusma mevcut idi. Literatürde başlangıç bulgusu olarak GiS bulguları görülen hastaların oranı $\%$ 14-20 olarak belirtilmektedir [1-3].

Bu hastalarımızdan 2'si karın ağrısı nedeniyle apendektomi geçirmiş, HSP tanısı, operasyonun ardından, purpurik döküntülerin çıkması ile konulmuştur. Literatürde HSP'nin cerrahi yönünü değerlendiren bir çalışmada HSP'li 110 çocuktan 12 'sinde laparatomi uygulandığı, bunlardan altısına apendektomi yapıldığı bildirilmiştir [4].

Hastalarımızda döküntülerin \% 25,5 oranında eklem ağrısından sonra ortaya çıktığı bulundu. Literatürde başlangıç bulgusu olarak eklem bulgusu görülen hastaların oranı ortalama $\% 25$ oranında bildirilmiştir [1,2].

Hastalarımızda \%26,5 oranında hastaneye yatırıldığı anda veya daha sonraki günlerde, en az bir kez saptanan $37,5^{\circ} \mathrm{C}$ 'nin üzerinde ateş saptandı. Literatürde HSP'li hastalarda \% 75 oranında $38{ }^{\circ} \mathrm{C}$ 'den düşük, hafif bir ateş saptanabileceği bildirilmiştir [2].

Hastalarımızın \%55'inde döküntüden 1-4 hafta önce ÜSYE enfeksiyonu öyküsü vardı. Literatürde yapılan bir çalışmada HSP'li çocukların üçte ikisinde HSP semptomlarından 2-3 hafta önce enfeksiyon belirtileri bulunmuştur [5]. Ancak etyolojide streptokoksik enfeksiyonun tek başına etken olmadığı hastalığın etyopatogenezinde konağın kendisinden ve çevresinden kaynaklanan etkenlerinde rol aldığı düşünülmektedir $[1,6]$.

Hastalarımızda en sık görülen bulgular sıklık sırasına göre palpabl purpura, GiS tutulumu, böbrek tutulumu ve eklem tutulumu idi.
2016; 7 (4): 269-277

doi: 10.5799/ahinjs.01.2016.04.0609

Çalışmamızda \% 43,1 oranında bulduğumuz eklem tutulumu diğer çalışmalarda \%60-80 arasında değişen oranlarda bildirilmiştir $[2,6]$. Bizim çalışmamızda bu oranların düşük çıkması, artralji gibi eklem şikayetlerinin daha subjektif şikayetler olması ve küçük çocuklarda ifade edilememesi şeklinde açıklanabilir.

Çalışmamızda \% 28,4 oranında bulduğumuz renal tutulum önceki çalışmalarda \%18-80 arasında değişen oranlarda bildirilmiştir. Bu çalışmalarda Uzak Doğu ve Orta Doğu kaynaklı yayınlarda renal tutulumun daha sık, Avrupa kaynaklı olanlarda daha seyrek olarak bildirilmesi dikkat çekicidir ve bizim bulgumuz literatür ile uyumlu bulunmuştur $[2,6,7]$.

Hastalarımızın \% 6,9'unda hematemez, \% 9,6'sında ise melana saptanmıştır. Literatürde de hematemezin \% 7-8, melena ise \% 18,6 oranında görülebileceği ve GiS kanamalarının kan transfüzyonu gerektirmeyen, ciddi olmayan kanamalar olduğu belirtilmektedir [2-4].

Hastalarımızın hiç birinde intussusepsiyon, barsak infarktı veya perforasyon saptanmadığı gibi, hiçbir hastaya GiS komplikasyonu nedeni ile akut cerrahi girişim uygulanmamıştır. Literatürde \% 5 oranında masif gastrik kanama olabileceği, \%2-3 oranında intussusepsiyon görülebileceği, barsak infarktı ve perforasyonun çok nadir olduğu, \%2-6 oranında acil cerrahi girişim gerektiren durumların ortaya çıkabileceği belirtilmektedir [2-4].

Böbrek tutulumu saptanan hastalarımızın yaş ortalaması 9,2 yıl olarak bulundu. Böbrek tutulumu bulunan hastalarımızın en küçüğü 3 yaş en büyüğü 14 yaşında idi. Böbrek tutulumu bulunan 29 hastanın $25^{\prime} \mathrm{i}(\%$ 86,2) yedi yaş üzerinde idi. Kaku ve arkadaşlarının yaptığı çalışmada HSP'li çocuklarda renal tutulumun yedi yaş üzerinde daha sık görüldüğü bildirilmiştir [7]. Böbrek tutulumu bulunan 29 hastanın \%46'sında mikroskopik hematüri tespit edilip, en sık görülen böbrek bulgusu hematüri olarak saptanmıştır. Literatürde de en sık rastlanan ve en erken böbrek bulgusunun hematüri olduğu ve böbrek tutulumu olanların \%22-76'sında görülebileceği bildirilmiştir $[2,8]$. Ayrıca böbrek tutulumu bulunan 29 hastamızın 7 'sinde $\left(\begin{array}{ll}\% & 25\end{array}\right)$ makroskopik hematüri saptanmıştır. Literatürde genel olarak böbrek tutulumu olan hastaların \% 22-33 arasında 
değişen oranlarda makroskopik hematüri görülebileceği bildirilmiştir [2,8].

Böbrek tutulumu bulunan 29 hastanın 12'sinde (\% 41,3$)$ hafif ve orta derecede proteinüri saptanmıştır. Literatürde, böbrek tutumlu bulunan hastaların \%25-83 arasında değişen oranlarda proteinüri saptanabileceği belirtilmiştir [9].

Böbrek tutulumu bulunan hastalarımızda, GiS semptomları, diğerlerine göre daha yüksek oranda bulunurken, eklem tutulumuna daha düşük oranda rastlandı. Literatürde yapılan çalışmalarda GiS semptomların renal tutulum için risk faktörü içerdiği belirtilmiştir $[6,7]$.

Böbrek tutulumu bulunan hastalarımızda lökositoz, trombositoz, yüksek CRP, yüksek C3 ve eritrosit sedimantasyon hızı, yapılan diğer çalışmalarda da belirtilmiştir $[6,7,10]$. Bu sonuç, bu parametreleri yüksek olan HSP'li çocuklarda hastalığın daha şiddetli ve renal tutulum olasılığının daha yüksek olacağını düşündürmektedir

Erkek hastalarımızın \% 12,7'sinde testis tutulumu saptandı. Bunların 6'sında testiste ödem, 5'nde skrotum ve peniste purpura, 2'sinde skrotal ödem ve ağrı saptandı, bir hastada ise USG'de mesane içinde ekojenik görünüm mevcuttu. Literatürde testis tutulumu \% 12-38 arasında değişen oranlarda bildirilmiştir [2].

Henoch-Schönlein Purpurası mevsimsel olarak en sık sonbahar daha sonra sıklık sırasına göre kış, ilkbahar ve yaz aylarında yığılma göstermekteydi. İklim özellikle streptokoksik üst solunum yolu enfeksiyonlarının dağılımında önemlidir. Sonbahar ve kış aylarında hastalıkta artış görülmesi, üst solunum yolu enfeksiyonlarının etyolojideki rolünü desteklemektedir [2,11].

Hastaların ilk başvuru anındaki laboratuvar bulgularında en yüksek değerler sıklık sırasına göre; yüksek sedimantasyon hızı, yüksek C3, yüksek IgA, trombositoz, yüksek CRP, yüksek ASO, yüksek beyaz küre olarak bulundu. Literatürde yapılan çalışmalarda da sedimantasyon hızı ve trombosit sayısının inflamasyona bağlı olarak arttığı, lökosit sayısının normal veya yüksek olarak bulunabileceği, özellikle hastalığın akut fazında IgA ve C3 gibi enflamasyon göstergelerinin yüksekliğinin anlamlı olduğu vurgulanmıştır [2,3,12].

Kontrole gelen hastaların ilk başvuru anında yapılan renal USG'de anormal bulgu sıklığı son kontrollerindeki anormal renal USG bulgu sıklığından anlamlı olarak yüksekti. Ayrıca ilk başvuru anında, pozitif idrar bulgusu olanlarda, pozitif renal USG (grade artışı) sıklığı, normal idrar bulgusu olanlardan anlamlı yüksekti. Bütün bunlar USG'nin HSP'nin komplikasyonlarını tanımada ve hastalığın sistem tutulumu takibinde önemli bir non invaziv tanı aracı olduğu tezini güçlendirmektedir [13].

Hastalarımızın 42'sinde (\% 41,2) döküntü, 33 'ünde $(\% \quad 32,4)$ karın ağrısı tekrarladı. Purpurik döküntüleri tekrarlayan hastaların yaşları tekrarlamayanlardan anlamlı yüksekti. Literatürde de hastaların \% 5-50'sinde tekrarlama görülebileceği ve büyük çocuklarda daha fazla tekrarlama şansı olduğu belirtilmiştir $[2,14]$.

Çalışmamızda çalışmada, immunglobulin A düzeyi yüksek hastalarda GiS tutulumuna, sedimantasyon hızı yüksek olanlarda renal tutuluma daha sık rastlandı. Yedi yaş üstü çocuklarda GiS tutulumu yaşları küçük olanlara nazaran daha yüksekti. Ayrıca böbrek tutulumu büyük yaş, hipertansiyon varlığı ve $C 3$ düşüklüğü ile birliktelik gösterdi. Renal tutulumu olanlarda GiS semptomları, diğerlerine göre daha yüksek oranda idi. Bu sonuca göre hastaneye başvuru sırasında yedi yaşından büyük olan, C3 düşüklüğü, GiS tutulumu ve hipertansiyonu bulunan HSP'li hastalarda o anda renal tutulum bulunmasa bile, sonraki kontrollerde renal tutulum yönünden dikkatle izlenmeleri gerekmektedir. Bununla birlikte hastaneye başvuru anında $\operatorname{lgA}$ düzeyi yüksek hastalarda GiS tutulumu, sedimantasyon hızı yüksek hastalarda da renal tutulum yönünden dikkatli olunması gerekmektedir.

Sonuç olarak, renal tutulumla lökositoz, trombositoz ve C-reaktif protein yüksekliği arasındaki anlamlı korelasyonlar bu parametreleri yüksek olan çocuklarda renal tutulum açısından dikkatli olunması gerektiğini göstermektedir. Renal tutulumlu hastalarda ultrasonografi ile ekojenite artışının anlamlı olarak daha sık gözlenmesi, ultrasonografinin, renal tutulumu bulunan hastaların takibinde 
noninvazif yöntem olarak kullanılabilir olduğunu göstermesi açısından önemlidir.

Declaration of Conflicting Interests: The authors declare that they have no conflict of interest.

Financial Disclosure: No financial support was received

\section{KAYNAKLAR}

1. Chen JY, Mao JH. Henoch-Schönlein purpura nephritis in children: incidence, pathogenesis and management. World J Pediatr 2015; 11:29-34.

2. Lanzkowsky S, Lanzkowsky L, Lanzkowsky P. Henoch-Schönlein Purpura. Pediatr Rev 1992; 13: 130-137.

3. Sharief N, Ward HC, Wood CBS. Functional intestinal obstruction in Henoch-Schönlein purpura. J Pediatr Gastroenterol Nutr 1991;12:272-275.

4. Katz S, Borst M, Seekri I, Grosfeld JL. Surgical evaluation of Henoch-Schönlein purpura. Experience with 110 children. Arch Surg 1991; 126:849-853.

5. Storm K, Ostergaard JR. Infection as the precipitating factor in Schönlein-Henoch

purpura. (abstract) Ugeskr Laeger 1991;153:192-195.

6. Ece A, Gürkan F, Haspolat K, Katar S. HenochSchönlein purpuralı çocuklarda renal ve gastrointestinal tutulumla ilişkili klinik ve laboratuar bulgular. Çocuk Sağlığı ve Hastalıkları Dergisi 2000; 43:36-42.

7. Kaku Y, Nohara K, Honda S. Renal involvement in Henoch-Schönlein purpura: a multivariate analysis of prognostic factors. Kidney Int 1998;53:17551759.

8. Beşbaş N, Özaltın F. Sistemik vaskülit. Katkı Pediatri Dergisi. 1999;20:703-725.

9. Stewart M, Savage JM, Bell B, Mccord B.Long term renal prognosis of Henoch-Schönlein purpura in an unselected childhood population Eur J Pediatr 1998;147:113-115.

10. Mollica F, Li Volti S, Garozzo R, Russo G. Effectiveness of early prednisone treatment in preventing the development of nephropaty in anaphylactoid purpura. Eur $\mathrm{J}$ Pediatr 1992;151:140-144.

11. Bona G, Monti G. Henoch-Scöhlein syndrome in children. Clinico-epidemiologic analysis of 170 cases. Minerva Pediatr 1989; 41: 587- 592.

12. Saulsbury FT, Kesler RW. Trombocytosis in Henoch-Schönlein purpura Clin Pediatr 1983;22:185-187.
13. Laor $\mathrm{T}$, Atala A, Teele RL. Scrotal ultrasonography in Henoch-Schönlein purpura. Pediatr Radiol 1992;22:505-506.

14. Van EsLA, Kauffmann RH, Valentijn RM. Renal manifestation of systemic disease: Henoch-Schönlein purpura. In: Holiday MA, Barratt TM Vernier RL (ed). Pediatric Nephrology (2nd ed). Baltimore: Williams and Wilkins, 1987: 492-498. 